\title{
TESTIMONY WITHOUT HARMFUL EFFECTS: FULL PROTECTION OF THE CHILD VICTIM OF INTRAFAMILIAL SEXUAL ABUSE
}

\author{
Julia de Barros Caribé1, Isabel Maria Sampaio Oliveira Lima²
}

DOI: http://dx.doi.org/10.7322/jhgd.96801

\begin{abstract}
Introduction: intrafamilial sexual abuse of children is a social and public health problem. The investigation of crimes of this nature shows widespread and often irreversible psychological harm to the victims. The harmful effects arise from the act itself as well as the absence of special care for children, whose development is gradual and whose condition of being subjects with rights is often ignored. Interdisciplinary coordination among the fields of Law, Psychology, and Social Work is essential to reduce the extent of the damage. The coordination of these areas of expertise when put into practice leads to the non-victimization of the child. This interdisciplinary effort has gained prominence in the discussions of children's rights, and the possibility of its implementation in the project "Testimony without harmful effects" (DSD, acronym in Portuguese). Objective: to analyze the DSD (Depoimento Sem Dano) from the perspective of the full protection of the child. Methods: a qualitative approach, with a literature review, legislation review and semi-structured interviews. Results: there was a shortage of national literature on DSD. The interviews enabled the designation of four categories based on the analysis of the different points of view of DSD according to those interviewed: the actions of the legal professionals and the care for children; the need for change in the dynamic of listening to the child victim; positivity of the "DSD" project proposal; the effectiveness of the technique. Discussion: the most characteristic aspects of intrafamilial sexual abuse of children justify the use of the DSD technique and its integrative phases. Conclusion: there is an imminent need for an extensive discussion of the guarantee of and effectiveness of the human rights of the child victim of intrafamilial sexual abuse, of the child victim's treatment and of listening to the child in a judicial proceeding. Dialogue among the different areas of expertise involved in the protection of the child is essential for the effective success of new possibilities.
\end{abstract}

Key words: child sexual abuse, child advocacy, protection, sexual violence, domestic violence.

\section{INTRODUCTION}

Violence, one of the issues of greatest concern and importance in contemporary society, consists, primarily, of the conversion of an asymmetry in a hierarchical relationship of inequality, whose aim is to dominate, exploit and oppress, according to Araújo ${ }^{1}$. The author also states that violence is an action that objectifies the human being, in detriment to his quality as a subject. Forms of oppression and domination present in some relationships trigger conflict. This circumstance portrays the concrete expression of violence as a "social issue", whether by different means of coercion with the goal of gaining control, or to maintain power or gain privileges ${ }^{2}$.

Among the different contexts in which violence can be discussed, when the issue involves children, it is of greater concern. The vulnerability of children and their unique status of being in development, led to a legislative prioritization in provision 227 of the Constitution of the Federal Republic of Brazil, (CRFB, acronym in Portuguese) $(1988)^{3}$ and of article $6^{\circ}$ of the Statute of the Child and Adolescent ${ }^{4}$ (ECA, acronym in Portuguese). Among the many types of violence against children is sexual abuse, which can occur in different relationship contexts, including an intrafamilial context.

Sexual violence against the child is described by Faleiros ${ }^{5}$ as a crime, in the sense that it is transgresses human, ethical, cultural and legal limits. It is a violation of familial and social rules in which a tortious and inhumane sexual act is practiced against the child or adolescent.

Given the criminal nature of the act, the terminology used, according to Boarati, Sei and

1 Masters student in Family in Contemporary Society at the UniversidadeCatólica do Salvador, Bahia, Brazil (PPGFSC-UCSal, 2014). Attorney. Bachelor's degree in Law from the UniversidadeCatólica do Salvador, Bahia, Brazil.

2 Doctor of Public Health (ISC-UFBA, Brazil). Law Judge in the State of Bahia, Brazil (1990-2004). Nurse (UFJF, Brazil). Consultant for Children's Rights in East Timor (2007-2009). Post-doctoral Fulbright Scholarat the University of Notre Dame, USA (CCHR-Law School, 2012).

Corresponding author: juliabc89@hotmail.com

Suggested citation: Caribé JB, Lima IMSO. Testimony without harmful effects: full protection of the child victim of intrafamilial sexual abuse. Journal of Human Growth and Development. 25(1): 108-116

Manuscript submitted May 18 2014, accepted for publication Nov 162014. 
Arruda ${ }^{6}$ can vary depending on the approach taken. There is the terminology suggested by the World Health Organization (WHO), the medical community and social services community, in addition to differences among countries or even regions within countries. The authors of this article define sexual violence as the commission or attempt to commit any sexual act with a child by use of force or coercion, threats of harm by anyone, regardless of degree of relationship with the victim or of the environment in which the violence occurs. However, in this study the term "sexual abuse" is used due to its specificity and the approach of the subject matter which focuses on the intrafamilial context.

Sexual abuse is classified as a form of physical or psychological violence, without consent, in which the abuser takes advantage of the child's trust in him, or takes advantage of the superiority over the child. Such an individualistic attitude is used to attain sexual satisfaction, causing pyschological harm to the victim?

Once defined, sexual abuse can be divided into familial and non-familial.According to Guerra ${ }^{8}$, approximately $80 \%$ of cases of abuse are committed by family members or someone known to the victim or who has gained the victim's trust. There are five well-known incestuous relationships: fatherdaughter, brother-sister, mother-son, father-son, and mother-daughter.

Child sexual abuse is a public health issue due to its recurrence and subsequent repercussions. It is characterized by the formation of a web of difficulties and of psychological domination in which the child, due to his immaturity, cannot be held responsible for the abuse. Furthermore, if the abuse occurs in the child's home, perpetrated by a relative or caretaker who should be ensuring the child's psychological well-being, the emotional and cognitive damage is worse, as is damage to the family structure. The family should be a place of refuge and preparation for socialization and development of trust.

The reduced number of cases reported to authorities makes understanding the real situation more difficult. Frisa Azambuja ${ }^{9}$, however, states that even if the number of cases of intrafamilial sexual violence against the child that are reported to authorities is far less that than the true number of occurrences, the judicial system is responsible for ensuring children's full protection.The judicial system, according to the author, is responsible to take on the demand not met by the Guardianship Council and by the System of Protection and Guarantee, within its realm and responsibilities regarding children whose rights were threatened or violated.

It is incumbent upon the judicial system to solve the cases of sexual abuse and hold the aggressor responsible. Brazilian jurisprudence even its doctrine - espouses the notion that it is not always possible to prove a crime with material evidence. In crimes of a sexual nature, only on rare occasions is it possible to identify evidence on the body of the victim, and therefore the word of the child victim is of heightened importance. Therefore, the Supreme Federal Court states that "the doctrine and jurisprudence, including of this House, are based on the premise that 'when dealing with crimes against customs, the word of the victim gains special importance'"10.

Given the vulnerability of child and adolescent victims, cases of sexual abuse should be carefully handled and investigated. In this complex scenario, Drezett $\mathrm{J}$. et $\mathrm{al}^{11}$ state that legal professionals do not give adequate consideration to the concept and dynamic of sexual violence occurring within the family, a circumstance that negatively influences the trust of the professionals about the veracity of the facts provided by the victim.

Azambuja ${ }^{9}$ emphasizes the importance of considering short-term and long-term psychological and emotional consequences that each case of abuse can cause. During criminal proceedings of alleged intrafamilial child sexual abuse, feelings of guilt, shame, fear and even dubious feelings towards the alleged perpetrator can arise during the child's judicial hearing. These are only a few examples of factors that can arise from the judicial hearing and can adversely impact the obligation of full protection of the child, a fundamental principle that motivates Brazilian legislation on children's rights, including CRFB $^{3}$ (especially articles 6, 203 e 227) and regulated by $\mathrm{ECA}^{4}$, Law $\mathrm{n}^{\circ}$ 8.069. This principle has been evolving since the Geneva Declaration of the Rights of the Child of $1924^{12}$ (GDRC) and the Declaration of the Rights of the Child in $1959^{13}$ (DRC).The need for special protection was ratified by the Universal Declaration of Human Rights ${ }^{14}$ (UDHR) and enounced inthe Convention on the Rights of the Child ${ }^{15}$ (CRC).

In many cases, legal professionals lack training specific to this issue which leads to a failure to guarantee the protection of the child during the legal process. The lack of appropriate handling of child victims not only makes it more difficult to discover the abuse, but also increases the vulnerability of the child victim of sexual abuse. According to Florentino ${ }^{16}$, the unique needs of each case of child abuse presents a new challenge for professionals dealing with these cases.

In this context, Dobke ${ }^{7}$ attests to the overdue need for a new dynamic when listening to children victims of intrafamilial sexual violence. The method known as DSD is the first concrete step to change the issue in question in the current judicial system, since the the provision of evidence occurs with less harm to the victims. This need was recognized in the Proposed Law 7524 (PL 7524/ 2006)16, October 24, 2006, proposed Federal Congresswoman Maria do Rosário Nunes. Drawing inspiration from "Testimony without harmful effects", PL 7524/2006 proposes the inclusion of a new chapter in the Brazilian Penal Code (CP, acronym in Portuguese), which establishes procedural and adjudication standards for sexual crimes against children or adolescents or that have child or adolescent witnesses. Currently, it is on hold with the Board of Directors of the House Chamber since October 9, 2007.

The goal of this article is to assess the DSD project with the hope of affording full protection to the child. An analysis of recommendations 
stemming from this project, together with the obligation of full protection of the child, allows for an assessment of the project's sustainability and implementation. Full protection is the guiding principle of this project, which aims to ensure that the hearing of a child victim of intrafamilial sexual abuse does not become another moment of terror, but rather an opportunity to verify and elucidate the acts perpetrated and their consequences.

\section{METHODS}

The writing of this article included the following tasks: a literature review, a legislative review and interviews with social services and legal professionals that deal with the protection of the child victim of sexual abuse. The questionnaire was prepared and tested before conducting the semistructured interview.A qualitative approach was taken with the aim of gaining a deeper understanding of the relationships, processes and phenomena, that cannot be reduced merely to practical operations, and that explores a universe of meanings, aspirations, values, and attitudes ${ }^{17}$.

The purpose of the literature search, which provided a theoretical basis for the article, was to make connections between the topic in question and other problems, thus providing a broader view of the subject matter ${ }^{18}$. The main database used was Scielo ${ }^{19}$, where searches for scientific articles were conducted using the following search terms [in Portuguese]: "sexual violence"; "sexual abuse"; "intrafamilial sexual violence"; "intrafamilial sexual abuse"; "intrafamilial violence"; "testimony without harmful effects"; "listening to children"; "listening to children in a judicial proceeding"and"violence against children".Several articles were found after searching the Scielo database up until the year 2011. These references served to bolster theoretical premises with books and other academic literature on the topic.

The purpose of the legislative review was to investigate the legal recourses available for the full protection of the child from both a macro and micro perspective, in other words, first identifying general information, and then focusing on specifics and standards, starting in the international realm and them moving to the national realm.

The purpose of the semi-structured interview was to gain understanding of the role of the social workers and lawyers. The professionals chosen performed work that specialized in this area: Care
Services for Victims of Sexual Violence, known as VIVER Services. This service was created 12 years ago in the city of Salvador, by the Department of Public Safety of the State of Bahia.Using the criterion of having worked more closely with cases involving child victims of abuse, the following professionals were selected: two lawyers (a male and a female), and two social workers.

The decision to use social services and legal professionals was based on the facts that they are both from the applied social sciences fields, and that they share an interdisciplinary duty to protect the child victim of intrafamilial sexual abuse when the child speaks in judicial proceedings. The degree of interdisciplinary coordination is based on the breadth of the focus of these professionals, and there is an assessment of common ground as well.

The interview questionnaire had four free response questions with a few main points of interest. These questions were in regards to how the children are questioned in judicial proceedings, the need for a new method of listening (in judicial proceedings) to children victims of intrafamilial sexual abuse, the occasional change needed in testimony, the knowledge of the DSD Project and a professional opinion regarding the examples presented in the project and their effects on holding accountable the criminal actor. The interviews sought also to gauge the professional consideration of the relevance of the victim's testimony and the acknowledgment of children's testimony as evidence.

The questionnaire was sent by email following an initial face-to-face meeting with each of the participating professionals to answer questions regarding the goal of the research and aspects relating to the topic being studied, as well as for the signing of an Informed Consent Form. Along with the interview questionnaire, some material taken from the book "Testimony without Harmful Effects. An alternative for questioning children and adolescents in judicial processes." ${ }^{20}$ was also sent to help clarify any questions that may have been raised.

\section{RESULTS}

The literature search was conducted up until the year 2011 and turned up five articles strictly related to the topic in question, using the selected search terms, although other articles and books were consulted to complete the theoretical basis presented.

Table 1: Articles found in the Scielo database relevant to the main topic of this study:

\begin{tabular}{|c|c|c|}
\hline Araújo ${ }^{1}$ & 2002 & $\begin{array}{l}\text { Experiences with psychological care and guidance of families that suffered } \\
\text { intrafamilial violence after reporting or alleging child sexual abuse committed by } \\
\text { close relatives. }\end{array}$ \\
\hline Froner, Ramires ${ }^{21}$ & 2008 & $\begin{array}{l}\text { Literature search on care of child victims of intrafamilial sexual abuse in the judicial } \\
\text { system. }\end{array}$ \\
\hline Santos, Dell'Aglio ${ }^{22}$ & 2008 & $\begin{array}{l}\text { Characteristics of mothers of children victims of sexual abuse, considering aspects } \\
\text { such as emotional adjustment, the multigenerational component, and the reaction } \\
\text { of the mother when the abuse is revealed. }\end{array}$ \\
\hline Boarati, Sei, Arruda 6 & 2009 & $\begin{array}{l}\text { Theories about the emotional development of the child victim of sexual abuse and } \\
\text { possible interventions. }\end{array}$ \\
\hline Drezettet al ${ }^{11}$ & 2011 & $\begin{array}{l}\text { Influence of the medical forensic examination on holding criminally accountable } \\
\text { those accused of sexual violence against female adolescents. }\end{array}$ \\
\hline
\end{tabular}


While the literature search turned up publications on topics relevant to the main topic, it also demonstrated a lack of academic research on the DSD project itself. "Listing to children in legal proceedings", "investigative and legal procedures for sex crimes against children", "consequences and harm caused during the entire process of trauma" and "holding the aggressor accountable" were topics focused upon in the literature search.

Analyses of the topics in the articles researched and of the dynamics of the DSD Project were done to see where there was an intersection. Due to the lack of academic literature on the specific topic, it was critical to determine this intersection, given that the book "Testimony with harmful effects; an alternative for questioning children and adolescents in judicial proceedings" is a primary and original source on the topic, written by the project's creator. It was possible to align the characteristics of the entire context of the circumstances surrounding the child victim of intrafamilial sexual abuse found in the literature, with the considerations reported in the DSD project, to find an alternative to reduce harm to victims.

The compilation of responses from the interviews showed some points of agreement among the opinions of the all of professionals interviewed, and some points of agreement among only the social services professionals. Conflicting points of views were not found, however certain differences of opinion regarding the condition of the child in the context of a judicial proceeding were raised only by social workers. Thus, it was possible identify four topics common to all responses, but with differences in their content:

- The conduct of legal professionals and their care of children: considerations about conduct when listening to the victim during judicial proceedings;

- The need to change the dynamic of the listening process: affirmative and unanimous position about the question at issue, with diverging opinions among those interviewed;

- Positivity towards the DSD project proposal: demonstrated understanding among those interviewed about the Project and approval of its proposal, with some reservations;

- Effectiveness of the approach: positive view of this aspect, with one responder emphasizing the importance of a change within the judicial system in regards to the treatment of the victim.

\section{DISCUSSION}

\section{Intrafamiliarity and "the syndrome of the secret"}

The gravity of intrafamilial child sexual abuse is exacerbated by the opposing notions of family and violence. Froner and Ramires ${ }^{21}$ warn that the child lacks moral or psychological development to be able to consent to engage in sexual acts and, once the child is a victim of intrafamilial sexual abuse, suffers in an environment where the child should be protected by someone who is charged with her care.

Due to the fact that the abuse occurs within the family, it is often not reported to authorities responsible for preventing such crimes. The occurrence is kept in familial secrecy, often by the mother, who, even if not the abuser, can be financially and psychologically dependent on her partner/abuser. Keeping the secret or even negating the abuse causes the victim to feel discredited.

This situation, called "the syndrome of the secret" by Balbinotti23, gives the child the status of being responsible for the dissolution of the family, the imprisonment of the father, the death the mother or the child herself, among other psychological pressures. The inherent innocence of the child, together with keeping the secret, leads to the false notion of the existence of a special relationship between her and her abuser - a member of the family whom she cares about.

Some factors that foment the syndrome of the secret should be noted according to DaltoéCézar $^{20}$, especially: (a) the immaturity of the child victim of abuse, which obscures the abuse and its reporting; (b) manipulation by the abuser distorting the child's reality, who sees herself as responsible for the assaults; (c) the victim's fear of not getting any more attention or affection from the abuser, whom the victim loves; (d) the lack of medical evidence regarding the abuse, which feeds the victim's fear of being discredited. The author also warns of the feelings that can arise when the child truly understands the facts: a moment of shame and of fear - especially the perceived threat of losing her mother's love if the secret is discovered ${ }^{20}$.

\section{Underreporting of cases and lack of material evidence}

Even when cases are brought to the attention of authorities, and are subsequently registered and denounced by the office of the prosecutor, there are many difficulties encountered in the process of trying to hold the aggressor accountable. The characteristics of the abusive sexual act, as well as barriers that exist when dealing with the victim of sexual abuse - limitations of professionals or family members - are possible determining factors in the estimation that only one in 20 cases are reported ${ }^{24}$. Thus, the reality of the situation of violence is obscured. There is a need for continuous training of professionals to deal in an interdisciplinary fashion with the phenomenon, to understand violence as a health problem that requires commitment and special attention. ${ }^{30}$.

According to Balbinotti ${ }^{23}$, the response to a report of child sexual abuse should focus first on the protection of the child, and then on holding the aggressor accountable. However, this is not the case currently in Brazilian society. These are responsibilities of different institutions: the Guardian Council, whose policy for care of children and adolescents should ensure basic rights in the interest of their development; of the police, who should initiate an investigation of the crime; of the office of the prosecutor, who should initiate a 
criminal proceeding; the health care network; the criminal court. Protective measures are taken in accordance with article 101 of $\mathrm{ECA}^{4}$. After these steps, the office of the prosecutor becomes aware of the crime. At the same time, the police open an investigation because of the need for a preliminary investigation. Then, the child victim must undergo forensic examinations (such as examination of corpus delicti), that often revictimizes the child.

The processof listening to the child should be carefully handled, so that the right of full protection is not violated ${ }^{4}$. This process must not cause the child's re-victimization and should respect the child's condition, taking into consideration that the traumatic symptoms are more prevalent in the psychological realm. This factor can help in the identification of indexes of abuse using a psychosocial report, however, without the testimony of the abused child, the crime cannot be concretely confirmed ${ }^{25}$.

\section{Full protection of the victim and provision of evidence}

The criminal justice system acts almost exclusively to investigate facts to hold criminals accountable. This manner of operation, which includes the phase of police investigation, is inadequate according to Daltoé-Cézar ${ }^{20}$, since it compromises the effectiveness of the judicial system by treating the child insensitively and disregarding her condition of being a person in development, which causes her re-victimization.

Aiming to minimize these incompatibilities, adherence to the DSD Project proposals ${ }^{20}$ provides a new direction to be taken in the criminal proceedings of sexual crimes. Considering the obligation of full protection of the child, the new dynamic set forth in this project of listening to child victims of intrafamilial sexual abuse aims to prevent the child from reliving moments of horror. A victim would be questioned in the judicial proceeding in an appropriate environment and by a professional specialized and adequately prepared to ask questions and get answers from the child or adolescent.

Trindade ${ }^{26}$ explains that a specialist must focus on the child as the fundamental center of protection, both in regards to law and psychology. Specifically for child victims of abuse, who are in conditions of fragility and suffering, the question should be raised of whether the respective professionals have had adequate cultural, scientific, and ethical training to handle listening about the abuse. There should be a preliminary assessment of the sensibility needed to witness the sharing of an event of this nature, whose reverberation can be difficult for an adult as well.

In these circumstances, there is always a need to understand the specific state of development of the child, so that she is not exposed to uncomfortable situations. The best interest of the child should always take precedence, so that, for example, the child should not be called to give testimony in the presence of her parents if they are being tried or are in conflict ${ }^{27}$.

\section{The dynamics of the project}

The DSD process, according to DaltoéCézar ${ }^{20}$, is divided in three stages:

a) Initiation of the process. This stage is roughly 15 to 30 minutes and begins with serving the child's parent/guardian with a subpoena to appear in court, where a specialist responsible for listening to the child's testimony - a social worker or psychologist - would take the child and any persons present in support of the child to begin the process.

The goal of this stage, which is very delicate, is to prevent any contact between the child/ adolescent and the defendant, however brief, at the courthouse. This problem exists throughout the national justice system, since the buildings were not designed to prevent this type of occurrence. According to the author of the project, reports of victims becoming pyschologically traumatized are frequent. Thus, testimony given under the effect of such emotions often does not provide effective proof of the crime ${ }^{20}$.

b) Giving testimony or being questioned by the judge. This is the stage during which the judge's questions are transmitted to the specialist, by electronic means, and modified to suit the child. Such questions could be: open-ended ("What happened on the day that you stayed with your uncle when your parents were travelling?"); yes/no ("Did your step-father kiss you on the mouth when he was alone with you at home?"); closed-ended ("Did he kiss you on the mouth or the neck?"); or hypothetical ("If a big uncle kissed a little niece on the mouth, should she tell her daddy?"). This stage would last, as a rule, 20 to 30 minutes and would be video-recorded without interruption.

Once the questioning by the judge, according the method described above, has ended, the recording of image and sound would be transcribed within 72 hours. Then the transcription would be added to the case file, as well as a disk with the video recording of the testimony. ${ }^{20}$.

c) End of Process/Document Transfer.In this stage, which would last between twenty and thirty minutes, the specialist would remain with the child in a room prepared for the giving of the testimony, with the audiovisual equipment turned off, submitting the testimony, and taking necessary measures and delivering the child to protective care.

In this context, it is essential to consider the child's and adolescent's unique condition of development, her right to full protection, and freedom of expression and opinion, associating these ideas of the $\mathrm{ECA}^{4}$, with the guiding principles of the legal process and procedural and jurisdictional guarantees, such as the presumption of innocence, right to a defense, due process, motivation for decisions, among others, set forth, respectively, in article 50, items LVII, LV, LIV and article 93, item IX of $\mathrm{CRFB}^{3}$.

Daltoé-Cézar ${ }^{20}$ reaffirms the primary aim of the DSD project: the reduction of harm to children/ adolescents during the provision of evidence in court cases, whatever their nature, in which they are victims or witnesses. It also seeks to guarantee their rights to be taken at their word, which can only be 
accomplished if their condition as a person in development is respected.

\section{The interviews}

The conduct of legal professionals regarding the special care of children

All of the professionals interviewed expressed that the moment when a child victim of intrafamilial sexual abuse testifies in court is seen as an obstacle or challenge to be overcome, considering that she already had to give testimony before the trial phase. The lack of sensitivity on the part of the judges that preside over the questioning of a child was pointed out, literally, in the statements of a lawyer and a social worker. They noted the lack of concern, lack of appropriate language and care when questioning, whether judge, prosecutor or defense lawyer, what the sexual abuse meant to the victim and the feelings of fear and discomfort reported after the hearing.

\section{The need to change the dynamic of the hearings}

There is unanimity in favor of changing the current dynamic of hearings for child victims of intrafamilial sexual abuse. However, the professionals questioned had differing opinions on what changes should be made. Both lawyers are in favor of only one session of giving testimony, that should take place in an environment suited for children, that allows the child to express herself in the manner that she feels comfortable.The social workers expressed a different point of view: the substitution of questioning in a judicial setting with an evaluation by a specialist who would take a tailored approach when listening to the victim, would use carefully worded language, and that would not take place in court. They recognize the need for a change in mindset on the part of legal professionals. The social services professionals believe that the practitioners of the judicial system should consider the victims as subjects with rights, and who are sensitive and subjective.

"I believe that a dialogue among the different areas of knowledge is needed, respecting the uniqueness and the competencies of each, so that the victim can be respected to the maximum, preventing situations of stress and re-victimization." (Social worker with VIVER - Care Services for Persons in Situations of Sexual Violence).

\section{Positivity of the "Testimony without harmful effects" project}

All of the professionals interviewed claimed that they knew of the project and think well of the proposal, however, the social workers expressed reservations about their role, as well as that of psychologists, in this dynamic. They raise the possibility that the hearing could be conducted by other professionals, not necessarily from the areas cited (for example: health, education). The respondents question if in fact there is need for an interdisciplinary effort, and that since the goal is to avoid re-victimization, it would make sense for only one professional to question the child. The lawyers, on the other hand, believe DSD is a good alternative to hearing children victims of intrafamilial sexual abuse, and one of them emphasized the importance of interdisciplinary coordination to implement the method.

\begin{abstract}
"Unfortunately, it is still necessary to overcome the noise in communication amongst the disciplines of law, psychology, pedagogy and social services to arrive at a model that respects the peculiarities of each area without one imposing its logic on the others, given that each has their own ethical rules. "(Lawyer for VIVER - Care Services for Persons in Situations of Sexual Violence).
\end{abstract}

\section{Effectiveness of the method}

The lawyers interviewed believe that using the DSD method to listen to child vicitms of intrafamilial sexual abuse will result in a greater number of perpetrators being held accountable, given that the testimony of the victim is the most critical piece of evidence in sex crimes. The female lawyer raised the possibility of the judge being able to watch the testimony more than once without the child having to be questioned again, and the quality of the testimony given under special conditions, where the victim can express herself more freely. On this point, the social workers have differing opinions. One had the same opinion expressed by the lawyers, while the other questions a system that should guarantee the rights of the child and adolescent, despite being in agreement with the specialized approach. She believes that legal practitioners, as well as the system as a whole, should adapt and undergo training. This would provide victims with the special care required and the specialized preparation of professionals from other areas that deal with children, an important internal change for the justice system itself.

\section{The legislative review}

Reviewing the legislative history of issues that are subjects of debate is important in light of the effectiveness of the basic principles of the Right of the Child and the Adolescent: the unique condition of being a person in development and the full protection of the child according to articles $3^{\circ}$ and $6^{\circ}$ of ECA, Law n. 8.0694. To this end, the topic of interest was researched in legal texts, in addition to literature on child sexual abuse crimes and of the victim giving testimony in a criminal proceeding. Starting with broader topics and then focusing more specifically on the topics of interest, the legislative review turned up the following documents: GD (1924); UDHR (1948); DRC (1959); International Covenant on Economic, Social, and Cultural Rights (1966, ratified by Brazil in 1992); CSDC (1989); CRFB (1988); ECA (1990); 
International Covenant on Civil and Political Rights (1992); Brazilian Penal Code (modified in 2009) and Brazilian Code of Criminal Procedure ${ }^{28}$ (CPP, acronym in Portuguese). With regard to the latter legal instrument and the DSD, Dobke'notes that if the legal practitioners are not capable of questioning the abused child given the dynamic of sexual abuse and child language, they can appoint an interpreter, through whom the victim will be heard.

According to the author, this professional would be trained in developmental psychology and sexual abuse issues, to prevent additional harm while achieving the following goal: validating the victim's testimony as proof to convict the aggressor, if the abuse has occurred.

This suggestion put forth by Dobke ${ }^{7}$ is supported by article 293 of the CPP 28 , that guarantees witnesses and victims who do not know the national language, whether they are deaf-mute of cannot read or write, the obligatory intervention of someone which is capable of understanding them, as an interpreter appointed the court.

\section{CONCLUSIONS}

Among the factors that enable the collection of evidence for the crime of child sexual abuse, the testimony of the victim is considered the most effective to elucidate the facts that have transpired and is also what requires the most care to handle. This testimony, in the majority of cases, is the only element that connects the allegation with the alleged aggressor, which is why special care is required, at the risk of irreversibly compromising the process of discovering what actually took place and losing one of the most valuable pieces of criminal evidence 26 .

However, this is not the only goal of DSD. Getting concrete proof to hold the aggressor accountable

\section{REFERENCES}

1. Araújo MF. Violência e abuso sexual na família. Psicol Estud. 2002; 7(2):3-11. Doi: http:// dx.doi.org/10.1590/S1413-73722002000 200002.

2. Ribeiro MA, Ferriani MGC, Reis JN. Violência sexual contra crianças e adolescentes: características relativas à vitimização nas relações familiares. Cad Saúde Pública. 2004; 20(2): 456-464. Doi: http://dx.doi.org/10.1590/ S0102-311X2004000200013.

3. Brasil [internet]. Constituição da República Federativa do Brasil de 1988. [cited 2012 Apr 03] Available from: http://presrepublica.jusbrasil. com.br/legislacao/91972/constituicao-darepublica-federativa-do-brasil-1988.

4. Brasil [internet]. Lei no 8.069, de 13 de julho de 1990. Dispõe sobre o Estatuto da Criança e do Adolescente e dá outras providências. [cited 2012 Apr 03] Available from: http://www. planalto.gov.br/ccivil_03/leis/I8069.htm. also serves to protect the child, to make her believe in her word and in the importance of her well-being. Starting with this notion, the fundamental principles of the entire mobilization of the goals of the project in question are: full protection of the child which includes reduction of harm, and the goal of not revictimizing the child, applying fundamental constitutional principles, such as the right to a defense, in such a manner that it respects a person's dignity and honors the rights of children and adolescents.

The appreciation of children as subjects with rights implies a significant change in the old legal and cultural paradigms, and needs to be reinforced daily through multidisciplinary coordination of professionals who work with children and adolescents. The combination of knowledge and practices in the areas of law, psychology and social services is of great value to DSD with regard to full protection of the child victim of sexual abuse. The same can be said about the resumption of the debate of PL 7524/2006 16 , in light of the procedural progress that it represents on this topic.

Modifying accepted judicial methods to societal needs is an obligation of legal practitioners. To this end, it is relevant to note that knowledge comes from many different scientific areas, spanning different perspectives and visions, such that it becomes more complete and effective ${ }^{20}$.

The analysis conducted of the results of the literature review, the legislative review and the interviews ensures the full protection and best interests of the child - ideals to be upheld at the center of discussions about children and adolescents. The coordination of the legal field with the social sciences and humanities, through the application of DSD, proves to be an important tool to effectively reduce harm to child victims of sexual abuse perpetrated by family members.

5. Faleiros VP, Faleiros ETS, Cardoso CMC, Pacheco LA, Cavicchioli FR. Circuito e curtoscircuitos no atendimento, defesa e responsabilização do abuso sexual contra crianças e adolescentes do Distrito Federal. [cited 2012 Apr 04] Available from: recrianacional.org.br/ index.php?option=com_docman\&task.

6. Boarati MCB, Sei MB, Arruda SLS. Abuso sexual na infância: a vivência em um ambulatório de psicoterapia de crianças. Rev Bras Crescimento Desenvolv Hum. 2009; 19(3): 412-425.

7. Dobke V. Abuso Sexual: A inquirição das crianças, uma abordagem interdisciplinar. Porto Alegre: Ricardo Lenz Editor; 2001.

8. Guerra VNA. Violência de pais contra filhos:a tragédia revisitada. $3^{a}$ ed. São Paulo: Cortez; 1998.

9. Azambuja MRF. Violência sexual intrafamiliar: Interfaces com a convivência familiar, a oitiva da criança e a prova da materialidade. Rev Tribunais. 2006; 95(852): 425-446. 
10. Brasil. Supremo Tribunal Federal. Habeas-

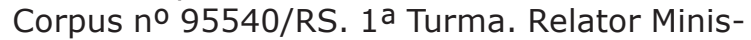
tro Ricardo Lewandowski. Julgado em 18/11/ 2008. [cited 2010 Sep 10] Available from: http://www.jusbrasil.com.br/jurisprudencia/ 2911032/habeas-corpus-hc-95540-rs-stf.

11. Drezett J, Junqueira L, Tardelli R, Antonio IP, Macedo Jr. H, Vertamatti MAF. Influência do exame médico-legal na responsabilização do autor da violência sexual contra adolescentes. Rev Bras Crescimento Desenvolv Hum. 2011; 21(2): 189-197.

12. Organização das Nações Unidas (ONU). Declaração de Genebra sobre os Direitos da Criança. Adotada pela Liga das Nações em 26 de setembro de 1924. [cited 2012 Jun 05] Available from: http://www.un-documents.net/ gdrc1924.htm.

13. Organização das Nações Unidas (ONU). Declaração dos direitos da criança. Proclamada pela Assembléia Geral das Nações Unidas em 20 de novembro de 1959. [cited 2012 Jun 05] Available from: http://198.106.103.111/ cmdca/downloads/Declaracao_dos_Direitos_ da_Crianca.pdf.

14. Organização das Nações Unidas (ONU). Declaração Universal dos Direitos Humanos. Adotada e proclamada pela Resolução 217 A (III) da Assembléia Geral das Nações Unidas em 10 de dezembro de 1948. [cited 2012 Apr 03] Available from: http://portal.mj.gov.br/sedh/ ct/legis_intern/ddh_bib_inter_universal.htm.

15. Convenção sobre os Direitos da Criança. Adotada e proclamada pela Resolução 1386 da Assembléia Geral das Unidas em 20 de novembro de 1989. Promulgada na República Federativa do Brasil com o Decreto no 99.710/90. [cited 2012 Apr 03] Available from: http:// www.planalto.gov.br/ccivil_03/decreto/19901994/D99710.htm.

16. Brasil. Câmara dos Deputados. Projeto de Lei 7524 (PL 7524/2006), de 24 de outubro de 2006. Acrescenta o Capítulo IV-A ao DecretoLei no 3.689, de 3 de outubro de 1941. [cited 2014 Jan 27] Available from: http:// www.camara.gov.br/proposicoesWeb/ fichadetramitacao?idProposicao $=334860$.

17. Minayo MCS. O desafio da pesquisa social. In: Minayo MCS, organizadora.Pesquisa Social. Teoria, método e criatividade. $22^{a}$ ed. Petrópolis: Ed. Vozes; 2003. p. 9-29.

18. Triviños ANS. Introdução à pesquisa em ciências sociais: a pesquisa qualitativa em educação. São Paulo: Atlas; 1987.
19. Scientific Electronic Library Online - SciELO. Available at: http://www.scielo.br/.

20. Daltoé-Cézar JA.Depoimento sem dano: Uma alternativa para inquirir crianças e adolescentes nos processos judiciais. Porto Alegre: Livraria do Advogado; 2007.

21. Froner JP, Ramires VRR. Escuta de crianças vítimas de abuso sexual no âmbito jurídico: uma revisão crítica da literatura. Paidéia. 2008; 18(40): 267-278.

22. Santos SS, Dell'Aglio DD. Compreendendo as mães de crianças vítimas de abuso sexual: ciclos de violência. Estud Psicol (Campinas). 2008; 25(4): 595-606.

23. Balbinotti C. A violência sexual intrafamiliar: a revitimização de crianças e adolescentes vítimas de abuso. Direito Justiça. 2009; 35(1): 5-21.

24. Azambuja MRF. Violência sexual intrafamiliar: É possível proteger a criança? Porto Alegre: Livraria do Advogado; 2004.

25. Lourenço APSL, Welter CLW, Ulrich LB. Considerações sobre o depoimento de criança/adolescente vítima de violência sexual [in-ternet]. Ministério Público do rio Grande do Sul. [cited 2011 Mar 18] Available from: http:// www.mp.rs.gov.br/areas/infancia/arquivos/ antecipacao_de_prova.pdf.

26. Trindade J. Manual de Psicologia Jurídica para operadores do Direito. $4^{a}$ ed. Porto Alegre: Livraria do Advogado; 2010. p. 364.

27. Oliveira VCPSA. Considerações sobre a criança e o adolescente diante da Justiça nos crimes de abuso sexual infantil. In: Volnovich JR, organizador. Abuso Sexual na Infância.Rio de Janeiro: Lacerda; 2005.

28. Brasil. Decreto-lei no 3.689. Dispõe sobre o Código de Processo Penal Brasileiro (03 de outubro de 1941) [cited 2012 Jun 04] Available from: http://www.planalto.gov.br/ccivil_03/decreto-lei/del3689compilado.htm.

29. Florentino BRB. Abuso Sexual, Crianças e Adolescentes: reflexões para o Psicólogo que trabalha no CREAS. Fractal, Rev Psicol. 2014; 26(1): 59-70. Doi: http://dx.doi.org/10.1590/ S1984-02922014000100006.

30. Moreira GAR, Vasconselos AA, Marques LA, Vieira LJES. Instrumentação e conhecimento dos profissionais da equipe saúde da família sobre a notificação de maus-tratos em crianças e adolescentes. Rev Paul Pediatr. 2013; 31(2): 223-230. Doi: http://dx.doi.org/ 10.1590/S0103-05822013000200014. 


\section{RESUMO}

Introdução: o abuso sexual intrafamiliar contra crianças apresenta-se como um problema social e de saúde pública. A investigação de crimesdesta natureza acarreta inúmeros e, muitas vezes, irreversíveis danos psicológicos às vítimas. Os danos advêmtanto do ato em si quanto da ausência de cuidados especiais para crianças, cujo desenvolvimento é gradativo e cuja condição de sujeitos de direitos muitas vezes é ignorada. O trabalho interdisciplinar entre Direito, Psicologia e Serviço Social é fundamental na busca da redução de danos. A integração destes saberes com a prática convergem no processo da não revitimização da criança. Este esforço interdisciplinar ganha destaque nas discussões dos direitos da criança, tal a possibilidade de sua efetivação com o projeto "Depoimento sem dano" (DSD). Objetivo: analisar o DSD na perspectiva da proteção integral da criança. Método: abordagem qualitativa, com revisão de literatura, revisão legislativa e entrevista semiestruturada. Estas técnicas permitem compreender a interseção entre a proteção integral e a aplicação do DSD nos casos de abuso sexual intrafamiliar contra a criança. Resultados: verificou-se a escassez de produção acadêmica nacional acerca do DSD propriamente dito. As entrevistas possibilitaram a construção de quatro categorias temáticas a partir da análise dos pontos de vista acerca do DSD conforme os entrevistados: a atuação dos profissionais do Direito e o cuidado com a infância; necessidade de mudança na dinâmica da escuta da criança vítima; positividade da proposta do projeto "DSD"; eficácia da técnica. Conclusão: há iminente necessidade de ampla discussão da garantia e da eficácia dos direitos humanos da criança vítima de abuso sexual intrafamiliar, no seu tratamento e na sua escuta em juízo. Imprescindível também a interlocução entre as áreas do conhecimento engajadas na proteção da infância, para o efetivo sucesso de novas possibilidades.

Palavras-chave: abuso sexual na infância, defesa da criança e do adolescente, proteção, violência sexual, violência doméstica. 